\title{
Um Estudo Sobre o Financiamento da Política de Desenvolvimento Territorial no Meio Rural Brasileiro' ${ }^{1}$
}

\author{
Sergio Pereira Leite $^{2}$ e Valdemar João Wesz Júnior ${ }^{3}$
}

Resumo: O objetivo deste artigo é apresentar a performance da execução orçamentária do financiamento da política territorial, tomando-se como base o Programa de Desenvolvimento Sustentável dos Territórios Rurais (Pronat) e o Programa Territórios da Cidadania (PTC). Para tal exame foram entrevistados atores estratégicos destes programas e sistematizados os dados relacionados ao desempenho da política até 2009, analisando-se a composição dos recursos que viabilizam a mesma e as questões que facultam ou obstaculizam o fluxo de recursos necessários ao financiamento de despesas de custeio e investimento nas diferentes subfunções que compõem os programas. Os resultados deste trabalho mostram a complexidade e, ao mesmo tempo, as inovações que o arranjo institucional das políticas em escala territorial traz para a cena orçamentária, seja no que tange ao levantamento e lastreamento de fontes dos recursos alocados, seja no que se refere à forma de aplicação desses recursos segundo áreas geográficas e linhas programáticas de ação.

Palavras-chaves: Políticas públicas, desenvolvimento territorial, territórios rurais.

Abstract: The aim of this paper is to present the budget execution performance of the financing of territorial policy referring to the Sustainable Development Program of Rural Areas (Pronat) and Territories of Citizenship Program (PTC). To perform this study actors' strategic programs were interviewed and data on the performance of politics until 2009 were systematized. We analyzed the composition of resources that allow it, as well as issues that will enable or hinder the flow of resources required to finance operating expenses and investment in different subfunctions that compose programs. Results of this study show the complexity and, at the same time, innovations that institutional policies at territorial

1 Os autores agradecem aos pareceristas anônimos da revista pelos comentários e sugestões. O artigo apresenta os principais resultados de pesquisa desenvolvida com apoio do Instituto Interamericano de Cooperação Agrícola (IICA), em parceria com o OPPA/CPDA/UFRRJ.

2 Professor do Programa de Pós-graduação de Ciências Sociais em Desenvolvimento, Agricultura e Sociedade (CPDA), da Universidade Federal Rural do Rio de Janeiro (UFRRJ). Coordenador do Observatório de Políticas Públicas para a Agricultura (OPPA) e pesquisador-bolsista do CNPq. E-mail: sergioleite@ufrrj.com.br

3 Doutorando do Programa de Pós-graduação de Ciências Sociais em Desenvolvimento, Agricultura e Sociedade pela Universidade Federal Rural do Rio de Janeiro (CPDA/UFRRJ) com bolsa do CNPq e assistente de pesquisa do Observatório de Políticas Públicas para a Agricultura (OPPA/CPDA). E-mail: jwesz@yahoo.com.br 
level budget brings to the scene, whether regarding lifting and ballasting sources of allocated resources, whether regarding the form of application of these resources according to geographical areas and lines of programmatic action.

Key-words: Public policies, territorial development, rural territories.

Classificação JEL: Q18.

\section{Introdução}

Um dos temas relativamente pouco explorados na crescente literatura sobre a política de desenvolvimento territorial no Brasil é aquele relativo ao processo de financiamento da política propriamente dita. Com exceção dos trabalhos desenvolvidos por José Garcia Gasques, do Instituto de Pesquisa Econômica Aplicada (Ipea) ${ }^{4}$, e das notas técnicas produzidas por EdélcioVigna, do Instituto de Estudos Socioeconômicos (Inesc) ${ }^{5}$, o tratamento das condições financeiro-orçamentárias para a implementação de políticas agrárias (com exceção do crédito rural) e/ou de desenvolvimento rural é relativamente escasso, reduzindo-se basicamente à apresentação de valores empenhados e pagos dentro de um determinado período de execução fiscal. Na área territorial, isso é ainda menos evidente. Ou seja, apesar do foco no desempenho das políticas na área, pouco se diz das condições de financiamento da política de financiamento das atividades territoriais.

Assim, o objetivo deste artigo é apresentar a performance da execução orçamentária do financiamento da política territorial tomando-se como base o Programa de Desenvolvimento Sustentável dos Territórios Rurais (Pronat) e o Programa Territórios da Cidadania (PTC), ambos com atuação num período relativamente recente. Para o exame dos programas em apreço foram sistematizados os dados relativos ao desempenho da política ao

4 Ver, por exemplo, Gasques e Bastos (2009).

5 Ver Vigna (2004; 2009; 2010; 2011; 2012). longo dos anos de sua implementação, analisada a composição dos recursos que viabilizam a mesma, e as questões que facultam ou obstaculizam o fluxo de recursos necessários ao financiamento de despesas de custeio e investimento nas diferentes subfunções que compõem os programas. No entanto, em alguns casos e/ou rubricas, não foi possível ter acesso detalhado aos dados do sistema, o que, todavia, não impediu a análise aqui proposta.

Para a realização desta pesquisa foi feito um levantamento e sistematização de fontes orçamentárias provenientes dos registros da Secretaria de Desenvolvimento Territorial, do Portal dos Territórios da Cidadania e da Secretaria do Tesouro Nacional (Siafi/STN). Além disso, realizaram-se, entre agosto de 2009 e março de 2010, 33 entrevistas semiestruturadas com representantes de instituições diretamente ligadas ao tema proposto em Brasília (DF) e nos territórios do Noroeste Colonial (RS) e do Baixo Amazonas (PA).

Além da Introdução, este artigo está divido em três partes. Inicialmente analisamos as linhas de ação do Pronat e a distribuição dos recursos, além da sua execução financeiro-orçamentária. No tópico seguinte fizemos um exercício semelhante com o Programa Territórios da Cidadania que, mesmo tendo sido implementado há pouco tempo, oferece algumas pistas a respeito do tema que estamos privilegiando nesse artigo. Nas considerações finais apontamos os avanços e desafios encontrados na execução orçamentária do financiamento da política territorial. 


\section{O Programa de Desenvolvimento Sustentável dos Territórios Rurais}

A implementação das políticas territoriais na área rural herdou os erros e acertos de um programa anterior - o Programa Nacional de Fortalecimento da Agricultura Familiar (Pronaf), na linha "Infraestrutura e Serviços" - vigente no país da segunda metade dos anos 1990 até 2002. Como destacado por alguns estudos no assunto (cf. HESPANHOL, 2006), esse programa destacou-se pela atuação em municípios relativamente precários na área agrícola, por meio de um repasse médio de $\mathrm{R} \$ 150$ mil anuais, durante quatro anos, direcionados a uma pauta de ações definidas pelos Planos Municipais de Desenvolvimento Rural (PMDRs), discutidos no âmbito dos Conselhos Municipais de Desenvolvimento Rural (CMDRs), cuja existência (e certa paridade entre atores governamentais e entidades representativas dos agricultores familiares) era obrigatória para o recebimento dos recursos. Dessa forma, portanto, a articulação e o financiamento das atividades previstas pelo programa davam-se entre as esferas nacional e estaduais e aquela fundada no município.

Ao longo da implementação do Pronaf Infraestrutura e Serviços, algumas dificuldades de caráter espacial acabaram aflorando, questionando a pertinência e a viabilidade da unidade municipal enquanto lugar de planejamento e organização de esforços visando à promoção do desenvolvimento rural (DELGADO e ZIMMERMANN, 2008; ABRAMOVAY e VEIGA, 1999). Além disso, em várias localidades brasileiras ficou evidente que o poder público municipal (prefeituras) atuava sob uma lógica clientelista e altamente subordinada aos interesses das oligarquias locais, comprometendo a demanda dos projetos e a sua execução. Ao mesmo tempo, muitas dificuldades enfrentadas pelos municípios indicavam uma escala mais ampla para sua resolução, tornando necessária a intervenção de políticas públicas de caráter supramunicipal (LEITE et al., 2007; HESPANHOL, 2006).

Em 2003, no início do Governo Lula, foi criado o Programa de Desenvolvimento Sustentável dos
Territórios Rurais (Pronat), que instituiu um novo formato de política ao optar pela construção de uma nova institucionalidade - o território -, fundado na representação dos interesses sociais e econômicos da agricultura familiar e que previa a coordenação e a articulação de um grupo de municípios em torno de uma estratégia comum (LEITE et al., 2007; TORRENS, 2007).

A emergência de uma instância supramunicipal de atuação das ações de desenvolvimento rural constituiu-se de imediato num avanço institucional, secundarizando o papel das prefeituras na implementação das políticas dessa natureza. Outra inovação do Pronat em relação ao Pronaf Infraestrutura e Serviços foi a ampliação da participação de representantes da sociedade civil nos Colegiados de Desenvolvimento Territorial (Codeter), que geralmente é de $2 / 3$ dos componentes, enquanto que na política precedente era paritário.

\subsection{Linhas de ação do Pronat e a distribuição dos recursos}

O Pronat foi construído a partir da inclusão em seu portfólio de duas modalidades do Pronaf: "Infraestrutura e Serviços Municipais" e "Capacitação dos Agricultores Familiares". Essas duas linhas deixaram de fazer parte do Pronaf (que ficou restrito ao crédito rural) e passaram a compor o Pronat por meio das funções: "Apoio a Projetos de Infraestrutura e Serviços em Territórios Rurais (Proinf)" e "Capacitação de Agentes de Desenvolvimento". Paralelamente foram agregadas duas outras ações na política pública em análise, ainda que não estivessem acopladas na sua matriz orçamentária: "Assistência Financeira Mediante Emendas Parlamentares" e "Projeto Dom Helder Câmara (PDHC) - Desenvolvimento Sustentável para os Assentamentos da Reforma Agrária no Semiárido do Nordeste".

Contudo, no contexto do desenvolvimento de territórios rurais, essas ações acabaram mostrando-se insuficientes, tornando evidente a necessidade de ampliar as opções de intervenção no Pronat. Nesse sentido, foi criada, em 2004, 
a linha "Elaboração de Planos Territoriais de Desenvolvimento Rural Sustentável (PTDRS)" e "Gestão Administrativa do Programa". Em 2006, foi instaurado o "Apoio à Gestão de PTDRS", buscando qualificar o processo de planejamento dos territórios rurais apoiados pela política. Em 2007, instituiu-se a ação "Fomento aos Empreendimentos Associativos e Cooperativos da Agricultura Familiar e Assentamentos da Reforma Agrária". Por fim, em 2008, foi criada uma linha que procura fortalecer iniciativas territoriais de conservação e manejo sustentável da agrobiodiversidade ("Fortalecimento e Valorização de Iniciativas Territoriais de Manejo e Uso Sustentável da Agrobiodiversidade").

A fonte básica dos recursos que compõem as funções do programa é totalmente lastreada pelo Orçamento Geral da União (OGU), incluindo os recursos aportados pelas emendas dos congressistas. Portanto, são recursos formados pelo Orçamento Fiscal, da Seguridade e pelo Orçamento de Investimentos das Empresas Estatais Federais, recolhidos sob a forma de impostos, taxas e contribuições.

Os recursos previstos em cada uma dessas linhas para a execução das atividades previstas nos territórios são intermediados pela Caixa Econômica Federal (CEF), que é a única instituição bancária envolvida no repasse dos recursos do
Pronat. Ela cobra 2,5\% sobre os projetos para a sua operacionalização, sendo $0,5 \%$ quando o projeto é emitido, $0,5 \%$ quando é contratado e 1,5\% na prestação de contas. Entretanto, em 2004 foi feito um convênio com o Banco do Nordeste (BNB) e criada uma unidade gestora para esse tipo de operação na perspectiva de que essa entidade pudesse atuar na região. Durante os quatro anos de convênio nenhum projeto foi operacionalizado porque o $\mathrm{BNB}$ não possuía estrutura para absorvê-los. Com o Banco do Brasil (BB) também ocorreram algumas tentativas, mas a taxa sobre os projetos intermediados era demasiadamente custosa se comparado com a CEF. Já o Banco da Amazônia (Basa) apresentava interesse, mas não tinha, assim como o BNB, estrutura suficiente para o seu funcionamento. Deste modo, a CEF mantém-se enquanto único agente financeiro responsável pelo repasse de recursos do Pronat.

De 2003 até 2007, houve aumento significativo do volume dos recursos contratados pelo Pronat (Figura 1), que passaram de R\$ 82,7 milhões para R\$264,7 milhões (crescimento de 272\%). De 2007 a 2008, o valor contratado recuou aproximadamente R\$ 40 milhões, devido à diminuição dos recursos das emendas parlamentares. Enquanto todas as demais linhas ampliaram o orçamento para 2008, as emendas territoriais apresentaram baixa de $50 \%$ se comparado com o mesmo período do ano anterior.

Figura 1. Valor contratado no Pronat por ano (2003 a 2008) valores correntes (em R\$).



Fonte: Brasil/MDA/SDT (2009). 
Figura 2. Participação no valor contratado por linhas de ação do Pronat por ano (2003 a 2008).

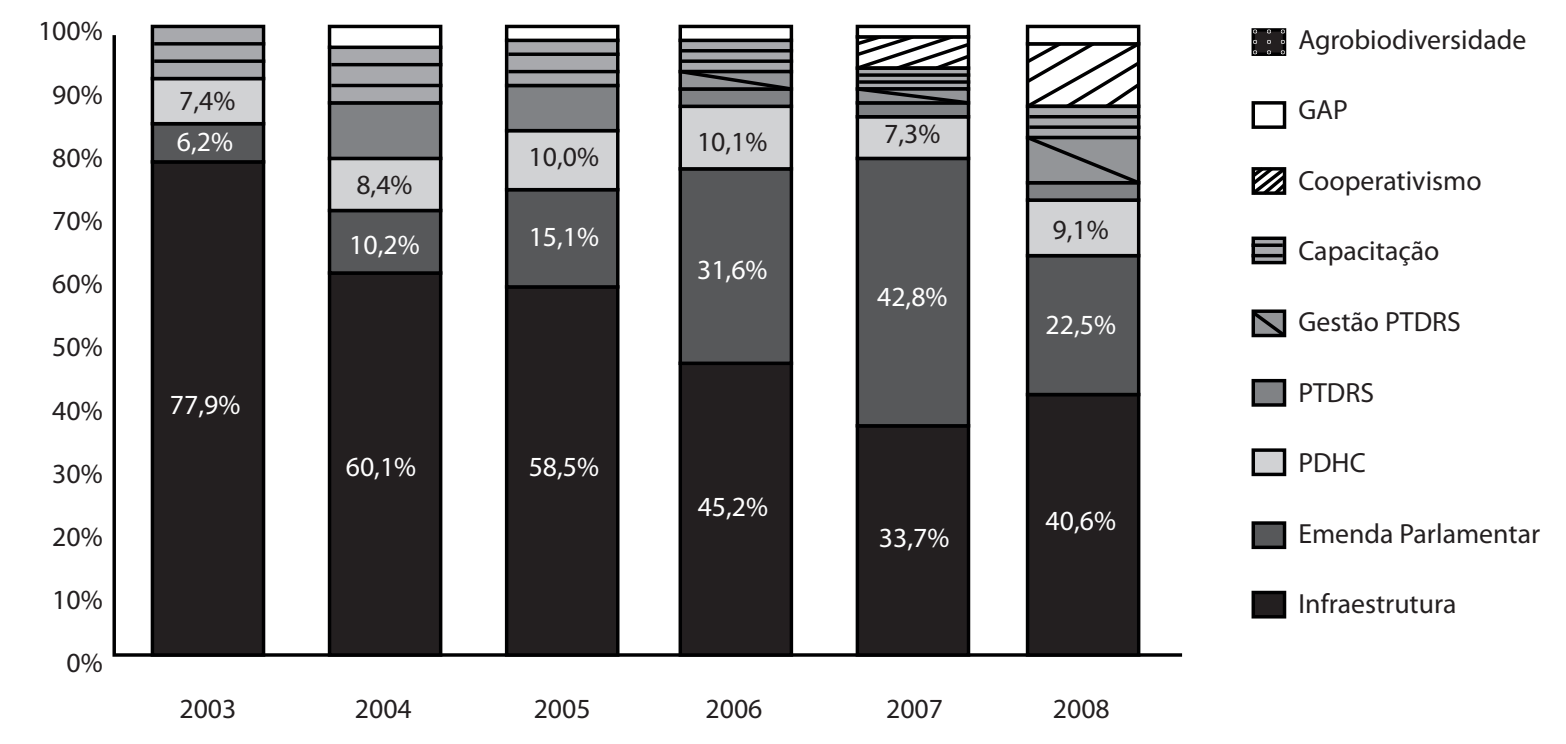

Fonte: Brasil/MDA/SDT (2009).

Um exercício interessante, apesar das diferenças temporais e dos distintos formatos de implementação dos programas, é analisar o montante contratado - em valores correntes - no Pronat (de 2004 a 2008) e no Pronaf Infraestrutura e Serviço (de 1997 a 2001). Ao se comparar a soma dos recursos nos respectivos cinco anos, percebe-se que o programa territorial apresenta volume $30 \%$ superior à política precedente. Entretanto, se o montante for dividido pelo número de municípios participantes, esse resultado se inverte, pois o valor médio por localidade é $30 \%$ maior no Pronaf, que cobria 1.253 municípios contra 2.500 no Pronat (em 164 Territórios Rurais).

Ainda que as diferentes linhas do Pronat possuam suas distintas funções e papéis dentro da perspectiva do programa, as ações voltadas prioritariamente ao investimento (Proinf e emendas parlamentares) são as modalidades que absorvem mais de $80 \%$ dos recursos contratados de 2003 a 2008. Entretanto, conforme a Figura 2, houve uma modificação nessa condição em 2008, pois é o primeiro ano em que as linhas de custeio alcançaram mais de $25 \%$ do valor total do Pronat. Essa ampliação não se observa na mesma intensidade em termos absolutos, pois não ocorreu um aumento do montante de recursos dessas modalidades, mas, sim, a queda das emendas parlamentares, que despencaram de 2007 para 2008, como foi comentado anteriormente. Se por um lado as emendas contribuem ao agregar um maior montante de recursos ao Pronat, por outro, esta modalidade imprime elevada vulnerabilidade orçamentária ao programa, ficando dependente dos interesses dos parlamentares.

Tanto os recursos para capacitação quanto para construção do PTDRS e Gestão e Administração do Programa (GAP) apresentaram redução significativa nos valores contratados até 2007. Esse decréscimo tem ocorrido porque são modalidades direcionadas essencialmente para os primeiros anos de um território, perdendo importância posteriormente. É por isso que houve aumento expressivo dos valores em 2008, tanto em termos relativos quanto absolutos, pois foram criados 45 novos Territórios Rurais em 2007, reabrindo a demanda nestas linhas.

Mesmo com essa redução das emendas em 2008, a Figura 2 torna evidente a importância das ações que complementam a matriz orçamentária do Pronat ("Assistência Financeira Mediante Emendas Parlamentares" e "Projeto Dom Helder Câmara - PDHC"), pois ambas as modalidades representam $34 \%$ dos valores contratados pelo 
Programa entre 2003 a 2008. Em alguns períodos, como em 2007, essas rubricas chegaram a representar mais de $50 \%$ de todos os recursos contratados pelo Pronat. Deste modo, não se pode dizer que essas ações são meramente complementares, pois desempenham papel central e de suma importância para a ampliação do potencial financeiro do programa.

A distribuição regional do Pronat aponta que em 2008 havia uma concentração de 40\% dos recursos contratados no Nordeste, enquanto que no Norte e no Sul esse valor fica próximo dos $20 \%$ e, no Centro-Oeste e Sudeste, dos 10\%. Se comparar os dados do Pronaf Infraestrutura e Serviços (em 2000) com o Pronat (em 2008), fica evidente uma relativa correspondência dos valores, demonstrando que os recursos mantêm a correlação espacial. A única diferença é que, no Pronaf, a região Sudeste tinha $22 \%$ e a região Norte, $12 \%$, resultados que se invertem no programa territorial.

\subsection{Execução financeiro-orçamentária do Pronat}

Antes de entrarmos nos valores da execução financeiro-orçamentária referentes ao Pronat, cabe retomar rapidamente as diferentes fases e procedimentos que envolvem esse processo. Inicialmente têm-se o valor previsto, que é definido e programado a partir dos recursos totais da Secretaria de Desenvolvimento Territorial (SDT) na Lei Orçamentária Anual (LOA). Em seguida, define-se o valor disponibilizado que se refere à LOA, isto é, o orçamento aprovado pelo Congresso Nacional e sancionado pelo
Presidente da República acrescido ou subtraído por eventuais créditos adicionais e/ou remanejamentos/contingenciamentos (limitação de empenho e movimentação financeira).

A transição do orçamento disponibilizado ao empenhado (valor empenhado) acontece quando os projetos já foram aprovados pela SDT e são encaminhados à CEF para a sua emissão no orçamento. A partir daí, a CEF entra em contato com o proponente para a contratação dos projetos (valor contratado), solicitando os comprovantes de adimplência da entidade e a documentação técnica do projeto - na falta de alguns destes documentos, assina-se o contrato com cláusulas suspensivas, informando que as pendências serão resolvidas até um período pré-determinado. Com a execução física do projeto e o cumprimento das cláusulas suspensivas, os valores passam a ser pagos aos proponentes (valor pago), finalizando a execução orçamentária do programa.

Em 2003, por ser o primeiro ano do governo Lula e por ter um processo de transição do Pronaf Infraestrutura e Serviços Municipais para o Pronat, ocorreu uma redução de mais de $40 \%$ entre o orçamento previsto e o disponibilizado no programa (Tabelas 1 e 2). Como houve nesse período um contingenciamento de recursos no âmbito do Ministério do Desenvolvimento Agrário (MDA), as políticas que estavam em processo de estruturação acabaram sofrendo constrangimento orçamentário. Paralelamente, um fator central para essa conjuntura se deve às emendas parlamentares, que ficaram somente com $10 \%$ do seu orçamento previsto devido ao elevado contingenciamento.

Tabela 1. Execução financeiro-orçamentária do Pronat por ano 2003/2008 - valores correntes em R\$.

\begin{tabular}{ccccccc}
\hline Ano & Previsto & Disponibilizado & Empenhado & Contratado & Pago & Pago/Previsto \\
\hline 2003 & 168.582 .306 & 96.426 .553 & 88.843 .740 & 82.761 .477 & 58.632 .213 & $34,8 \%$ \\
2004 & 132.101 .666 & 126.922 .680 & 122.380 .335 & 106.644 .432 & 106.456 .351 & $80,6 \%$ \\
2005 & 150.241 .090 & 135.049 .077 & 134.370 .012 & 127.448 .687 & 111.213 .745 & $74,0 \%$ \\
2006 & 213.774 .918 & 175.804 .654 & 169.809 .027 & 162.927 .821 & 146.924 .336 & $68,7 \%$ \\
2007 & 312.328 .314 & 280.522 .082 & 276.313 .238 & 264.753 .024 & 184.766 .156 & $59,2 \%$ \\
2008 & 297.384 .630 & 268.645 .331 & 259.673 .210 & 224.819 .449 & - & - \\
\hline
\end{tabular}

Fonte: Brasil/MDA/SDT (2009). 
Tabela 2. Valor retido nas diferentes fases da execução financeiro-orçamentária do Pronat por ano 2003-2008 (orçamento previsto $=100 \%$ ).

\begin{tabular}{cccccc}
\hline Ano & Previsto & Disponibilizado & Empenhado & Contratado & Pago \\
\hline 2003 & $100,0 \%$ & $57,2 \%$ & $52,7 \%$ & $49,1 \%$ & $34,8 \%$ \\
2004 & $100,0 \%$ & $96,1 \%$ & $92,6 \%$ & $80,7 \%$ & $80,6 \%$ \\
2005 & $100,0 \%$ & $89,9 \%$ & $89,4 \%$ & $84,8 \%$ & $74,0 \%$ \\
2006 & $100,0 \%$ & $82,2 \%$ & $79,4 \%$ & $76,2 \%$ & $68,7 \%$ \\
2007 & $100,0 \%$ & $89,8 \%$ & $88,5 \%$ & $84,8 \%$ & $59,2 \%$ \\
2008 & $100,0 \%$ & $90,3 \%$ & $87,3 \%$ & $75,6 \%$ & - \\
\hline
\end{tabular}

Fonte: Brasil/MDA/SDT (2009).

Entre 2004 e 2007, o Pronat foi comprimindo as diferenças entre o orçamento previsto e o disponibilizado (Tabelas 1 e 2), estabilizando-as a um valor médio de 10,3\%. Deve-se atentar que essa perda continua atrelada basicamente aos recursos para investimento, que são responsáveis pelas maiores reduções ( $97 \%$ dos casos). A modalidade que obteve o maior decréscimo de contingenciamento no Pronat foi a emenda parlamentar, pois sozinha responde por $65 \%$ dos valores não disponibilizados entre 2003 e 2008. Cumpre destacar que essa situação "foge à governabilidade da SDT/MDA e, apesar de a Assessoria Parlamentar deste Ministério gestionar junto à Casa Civil, nem sempre consegue-se o descontingenciamento total desta parte do orçamento" (BRASIL/BGU, 2007, p. 15).

As demais linhas do programa, centradas especificamente no custeio, não tiveram cortes significativos ao passar da primeira para a segunda etapa da execução financeiro-orçamentária (3\%). Algumas exceções pontuais ocorreram com a linha de capacitação em 2003, quando ainda estava vinculada ao Pronaf, com o Projeto Dom Helder Câmara (PDHC) em 2005 e na Gestão e Administração do Programa (GAP) em 2006.

A transição do orçamento disponibilizado ao empenhado apresenta as menores baixas do processo de execução financeiro-orçamentária (em média 2,2\%). A estratégia utilizada pela SDT para que não ocorram perdas expressivas nessa etapa consiste na solicitação junto aos territórios de um número maior de projetos do que o necessário, o que possibilita a substituição das propostas reprovadas por aquelas que atestem a viabilidade necessária. Como o recurso a ser empenhado já está disponível ao Pronat, se o mesmo não for utilizado ele retorna ao Tesouro Nacional e não pode mais ser incorporado ao programa.

A partir dos recursos empenhados, a CEF procede a contratação dos projetos. Esse processo - entre o valor empenhado e o contratado apresentou no Pronat uma perda média anual de 6,5\% entre 2003 e 2008, sendo superior no Proinf $(10,4 \%)$. Três razões são centrais para entender esse resultado. A primeira é a inadimplência dos proponentes, que atinge principalmente as linhas de investimento, visto que estas precisam passar necessariamente por algum ente federado (prefeitura ou Estado), enquanto que o custeio permite a presença de Organizações Não Governamentais (ONGs). Em segundo lugar vem a falta da documentação exigida, que se refere principalmente à legislação ambiental e à posse da terra onde será executado o projeto. Esses problemas atingem principalmente o Norte e o Nordeste brasileiro, em especial os estados do Pará e Maranhão, onde a diferença entre o valor dos recursos empenhados e contratados ficou próxima aos 20\% em 2007.

Por fim, outra situação que reduz significativamente o valor contratado é a desistência do proponente, especialmente na linha de Infraestrutura. Isso tem ocorrido em nível municipal no período das eleições para prefeito, quando o governo vigente, mesmo com o projeto aprovado, opta por não seguir os encaminhamentos necessários, dado o temor de favorecer os adversários políticos, pois o investimento seria aplicado num momento posterior ao mandato vigente. Os dados das 
Tabelas 1 e 2 demonstram essa conjuntura, pois em ano de eleições municipais a perda média entre o valor empenhado e contratado no Pronat é de $12 \%$ (no Proinf esse valor chega aos 19\%) e nos demais anos fica em 4\% (6\% no Proinf). Essa situação apresenta variação significativa entre os estados, pois no Amazonas, Maranhão, Pernambuco e Rio de Janeiro a diferença entre o percentual empenhado e o contratado de 2007 e 2008 (ano com eleições municipais) foi superior a $30 \%$.

No Pronat, entre 2003 e 2007, os valores contratados em relação aos pagos apresentaram decréscimo de $11,7 \%$, sendo mais expressivo nas linhas de Infraestrutura e emendas parlamentares. O motivo principal que ocasiona o não pagamento de parte dos contratos, principalmente nas linhas de investimento, não é a falta de recursos financeiros, mas as cláusulas suspensivas não sanadas pelos proponentes (prefeituras em especial), o que impede a emissão de ordens bancárias (BRASIL/ BGU, 2006). Nas demais modalidades de custeio essas perdas são inexpressivas.

Todo o processo de definição do orçamento disponível (discussão das propostas pelo colegiado territorial, construção dos projetos pelos proponentes nos moldes sugeridos, envio ao Conselho Estadual e avaliação da SDT) acaba avançando até o quarto bimestre do ano (principalmente em ano eleitoral). Deste modo, mais de $90 \%$ dessas operações de contratação ocorrem em dezembro, pois não se conseguiu desvincular a apresentação dos projetos do ano orçamentário correspondente. Para que esse valor não retorne ao Tesouro Nacional, um procedimento muito comum tem sido a utilização da opção "restos a pagar" (RAP), quando o valor fica assegurado para o projeto, mas será liberado somente no ano seguinte. Isso permite que em 2009 ainda estejam sendo pagos projetos contratados em 2007.

Como já havíamos comentado anteriormente, os proponentes dos projetos do Pronat são os municípios (por meio das prefeituras), os estados e as ONGs. Os municípios, desde o início, foram majoritários nos valores contratados, principalmente por controlar os recursos vinculados às emendas parlamentares e à Infraestrutura (os 75\% que são direcionados ao investimento). Em termos relativos, as prefeituras têm reduzido de forma crescente a sua participação a partir de 2005, pois houve uma diversificação das linhas de custeio, as quais passaram a ser absorvidas pelas ONGs. Os estados, por sua vez, atuam nas mesmas modalidades que os municípios, mas apresentam percentuais menos expressivos, ainda que em 2003 e 2007 superassem os 30\% (cf. Figura 3).

Figura 3. Valor contratado no Pronat por entidade proponente e por ano (\%).

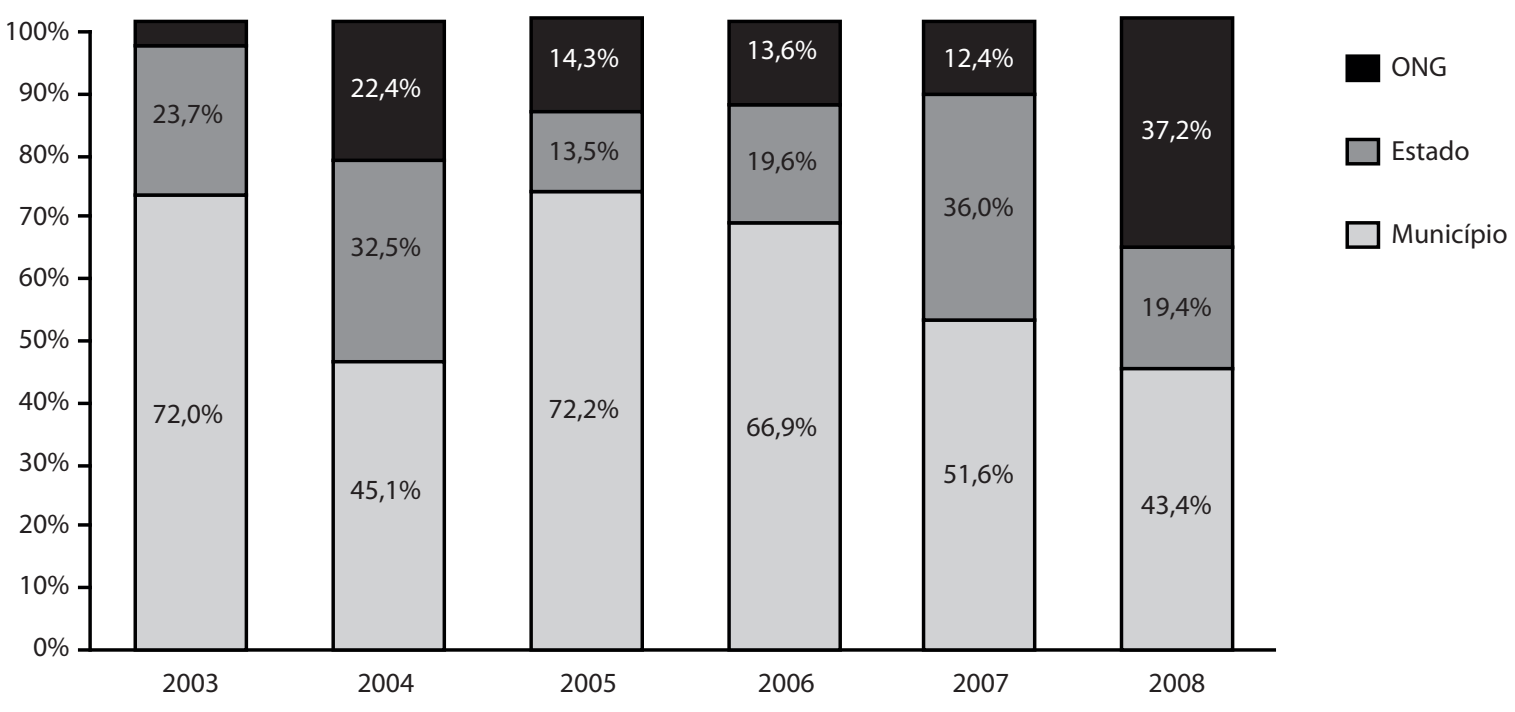

Fonte: Brasil/MDA/SDT (2009). 
As ONGs são as entidades que atuam na maioria dos projetos de custeio, em especial as modalidades de Capacitação, PTDRS, Gestão de PTDRS, Cooperativismo e PDHC. Nos últimos anos, a sua participação vem crescendo significativamente, atingindo, em 2008, mais de $35 \%$ dos valores contratados. Esse resultado está vinculado principalmente à cobertura das ONGs nas modalidades de Cooperativismo e Gestão de PTDRS. Não se pode desconsiderar também que a queda nos valores das emendas parlamentares em 2008 auxiliou sua expansão em termos relativos, pois as prefeituras e os estados viram uma das suas principais linhas apresentar perda de 50\% no valor contratado de 2007 para 2008.

A partir desta análise, pode-se dizer que o Pronat, ao longo dos anos, tem avançado na criação de novas linhas de ação, no aumento dos recursos disponibilizados e na redução das perdas ao longo das fases do processo de execução orçamentária. Contudo, o programa continua tendo decréscimos entre os valores disponibilizados e os valores pagos, principalmente no Proinf, que demanda mais tempo durante a construção das suas propostas e apresenta um trâmite administrativo mais carregado no momento de sua contratação. Caso semelhante tem ocorrido com as emendas parlamentares, com seu funcionamento fora do alcance da SDT, e registram perda de $50 \%$ dos recursos desde o momento da disponibilização até o pagamento. Em ambas as linhas ainda são presentes os problemas com a inadimplência dos proponentes, baixa qualidade técnica dos projetos, falta de documentação e interesse político, o que dificulta o pleno funcionamento das modalidades. Já as linhas de custeio, por apresentarem maior flexibilidade administrava e terem como proponentes entes não federados, detêm melhor aproveitamento na execução orçamentária.

\section{O Programa Territórios da Cidadania}

O Programa Territórios da Cidadania (PTC) foi lançado no início de 2008 e manteve a concepção de território e de abordagem territorial empregada no Pronat. $\mathrm{O}$ que se distingue é a ênfase no combate à pobreza e na conquista de cidadania como objetivos primordiais da intervenção governamental, assim como a mobilização de 22 ministérios no sentido de planejarem suas ações de modo a implementarem as políticas públicas correspondentes de forma integrada. Isso significa que já na esfera federal e não apenas nos territórios as políticas governamentais deverão ser coordenadas para agirem articuladamente.

No caso dos Territórios de Cidadania, diferentemente do Pronat, o desafio torna-se maior, pois envolve várias ações setoriais oriundas de distintos ministérios, cujo exercício de articulação se dará efetivamente na escala territorial, complexificando o processo de gestão social e, para ficarmos no tema deste estudo, de gestão financeiro-orçamentária. Muito mais que a mera somatória de ações e dotações orçamentárias dos ministérios sobre um mesmo espaço social, trata-se de pensar a lógica da territorialização de políticas a partir de um encontro de ações bottom-up, pelos atores locais - agora não necessariamente agrários - com aquelas top-down, também não necessariamente setoriais.

\subsection{Linhas de ação do PTC e a distribuição dos recursos}

Dentro do PTC foram definidos três eixos de atuação (Apoio a Atividades Produtivas; Cidadania e Direito; Infraestrutura), que se desdobram em sete temas (Organização Sustentável da Produção; Ações Fundiárias; Educação e Cultura; Direitos e Desenvolvimento Social; Saúde, Saneamento e Acesso à Água; 
Apoio à Gestão Territorial; Infraestrutura). No interior desses sete temas estão todas as ações do PTC (que em 2008 eram 180, em 2009 subiram para 203 e em 2010 reduziram-se para 178). Apesar de os eixos e de os temas apontarem para as prioridades do programa, são as ações os instrumentos diretos de intervenção, uma vez que os territórios passam a acessar os recursos por meio delas.

A partir da definição dos eixos e temas do PTC, é feita anualmente uma consulta junto aos ministérios buscando adesão ao programa por meio da oferta de ações (as quais compõem a Matriz Federal). Nesse caso, não se trata da criação, pelos órgãos federais, de novas políticas públicas para ingressarem no PTC, mas de destinar um volume de recursos dos programas já existentes aos Territórios da Cidadania. Deste modo, no momento em que um ministério passa a integrar o PTC não haverá maior dotação orçamentária para essa instituição, somente uma redistribuição dos valores buscando aumentar os recursos empregados nas regiões mais empobrecidas, menos dinâmicas etc., buscando melhorar a eficiência da sua aplicação no campo. Em outras palavras, os recursos dos ministérios não são ampliados; o que ocorre é que cada política setorial passa a direcionar uma parcela do seu montante de recursos para esse espaço através do PTC. Portanto, não ocorre um "aumento do bolo", somente uma nova redistribuição das suas fatias. Em alguns territórios - principalmente aqueles mais isolados - isso pode representar um acréscimo de recursos, enquanto que para outras localidades os valores têm poucas alterações, pois traduzem-se na mesma rubrica que já chegava aos municípios antes da sua constituição em Território da Cidadania.

É importante destacar que o PTC não influencia os processos decisórios de alocação de recurso dentro do ciclo de aprovação do orçamento de uma determinada política e/ou ação territorializada. Ou seja, cada ministério é responsável por apresentar e obter a aprovação junto ao Congresso Nacional dos seus valores totais a serem gastos a cada ano, de acordo com o funding ("carimbado" ou não) de que dispõem. A partir desse montante é que cada órgão definirá quanto irá repassar ao PTC. Do mesmo modo, a indicação das fontes dos recursos é de responsabilidade dos órgãos executores, integrando tanto recursos do Tesouro Nacional (OGU) quanto recursos não fiscais (que não passam pelo Tesouro Nacional) oriundos de organismos internacionais, de arrecadação própria, da exigibilidade dos bancos etc. Isso demonstra que o PTC procurou usar ao máximo as estruturas existentes, como consta no Decreto de 25 de fevereiro de 2008, que institui o programa.
As despesas decorrentes da execução dos projetos advirão das dotações orçamentárias próprias consignadas anualmente nos orçamentos dos órgãos e entidades envolvidas no Programa Territórios da Cidadania, observados os limites de movimentação, de empenho e de pagamento da programação orçamentária e financeira anual (BRASIL/ PRESIDÊNCIA DA REPÚBLICA, 2008, p. 3).

O que a coordenação do PTC tem feito é o acompanhamento dos valores dos ministérios que aderiram ao programa para que não ocorra uma redução no montante de recursos através do contingenciamento. Caso esse decréscimo seja inevitável, a Casa Civil e o Ministério do Planejamento pressionam os órgãos responsáveis pelas ações para que não subtraiam os recursos que são destinados ao PTC, procurando evitar que a não execução se justificasse por problema de redução dos valores previstos. Deste modo, o fato de estar em um Território da Cidadania acabava agregando estabilidade maior na manutenção dos recursos, enquanto os municípios que não participam do programa estão mais suscetíveis aos cortes orçamentários.

O fato de o PTC ser uma agregação de ações de diferentes ministérios faz com que ele não tenha um orçamento próprio (não existe na LOA nenhuma rubrica destinada ao Programa Territórios da Cidadania). Assim, o seu orçamento 
Tabela 3. Recursos previstos pelo PTC por tema (2008 a 2010) - valores correntes (em R\$).

\begin{tabular}{|c|c|c|c|c|}
\hline Tema & $\begin{array}{c}\text { Valor previsto } \\
2008 \text { (R\$) }\end{array}$ & $\begin{array}{c}\text { Valor previsto } \\
2009(\mathrm{R} \$)\end{array}$ & $\begin{array}{c}\text { Valor previsto } \\
2010(\mathrm{R} \$)\end{array}$ & $\begin{array}{c}\text { Cresc. } 2008 \text { - } \\
2010(\%)\end{array}$ \\
\hline Ações Fundiárias & $322.319 .943,45$ & $516.803 .123,47$ & $409.199 .000,00$ & $27,0 \%$ \\
\hline Apoio à Gestão Territorial & $19.918 .679,77$ & 23.348.610,09 & $34.183 .086,50$ & $71,6 \%$ \\
\hline Direitos e Desenvolvimento Social & $4.830 .370 .807,62$ & $9.098 .521 .324,58$ & $10.807 .542 .917,75$ & $123,7 \%$ \\
\hline Educação e Cultura & $563.423 .573,34$ & $1.342 .877 .879,36$ & $889.437 .224,10$ & $57,9 \%$ \\
\hline Infraestrutura & $3.150 .886 .020,39$ & $3.702 .870 .999,99$ & 4.454.268.091,77 & $41,4 \%$ \\
\hline Organização Sustentável da Produção & 2.452.374.482,58 & $5.943 .557 .001,43$ & 6.075.085.520,91 & $147,7 \%$ \\
\hline Saúde, Saneamento e Acesso à Água & $1.438 .889 .061,33$ & 4.297.359.313,41 & $4.137 .185 .725,60$ & $187,5 \%$ \\
\hline Total & $12.778 .182 .568,48$ & 24.925.338.252,33 & $26.806 .901 .566,63$ & $109,8 \%$ \\
\hline
\end{tabular}

Fonte: Brasil/Portal da Cidadania (2010).

é resultado da soma de orçamentos específicos. Isso torna, em grande medida, esta política pública refém da adesão dos órgãos federais e, automaticamente, dos seus recursos, o que deixa extremamente fragilizada sua estrutura orçamentária.

Em 2008, o valor previsto para os 60 Territórios da Cidadania chegou a R\$12,8 bilhões, que foi praticamente dobrado em 2009 com a entrada de mais 60 novos territórios. Em 2010, o montante de recursos ampliou-se em comparação com 2009 (alcançando R\$ 26,8 bilhões), atestando um crescimento expressivo de 109,8\% de 2008 para 2010. As linhas com maior incremento foram "Organização Sustentável da Produção" e "Saúde, Saneamento e Acesso à Água", que aumentaram o valor previsto em 187,5\% e 147,7\%, respectivamente. $\mathrm{O}$ tema com menor crescimento nesses três anos foi o de "Ações Fundiárias" (27\%), que apresentou, inclusive, redução de $20 \%$ nos valores absolutos de 2009 para 2010 (Tabela 3).

Existe uma concentração de recursos em três linhas gerais do programa (Direitos e Desenvolvimento Social; Infraestrutura; Organização Sustentável da Produção), pois aproximadamente $80 \%$ do montante fica retido nesses estratos (mais de $40 \%$ na área de "Direitos e Desenvolvimento Social" em 2010). No oposto estão as ações vinculadas à "Educação e Cultura", "Ações Fundiárias" e "Apoio à Gestão Territorial", ação que detinha somente $7 \%$ em 2008, caindo para 5\% em 2010. O tema da Gestão Territorial merece destaque especial porque, apesar de ser uma das inovações do PTC e apresentar um grande desafio na sua aplicação, ele responde por somente $0,1 \%$ dos recursos previstos no programa (R\$ 34 milhões em 2010).

Apesar de ocorrer aumento quase generalizado nos valores do PTC por ministério, esses órgãos possuem participação desigual no montante de recursos disponibilizados para as ações nos Territórios da Cidadania - característica que se mantém entre 2008 e 2010. Como mostra a Figura 4, apenas três ministérios (dos 22 participantes) concentram mais de $70 \%$ dos valores do programa (Ministério do Desenvolvimento Social e Combate à Fome - MDS, MDA e Ministério da Saúde MS). Quando tomamos os seis ministérios mais representativos em recursos disponibilizados, vemos que em 2010 eles expressam praticamente 96\% de toda dotação orçamentária focalizada no PTC - restando aos outros 16 ministérios apenas $4,1 \%$.

A Figura 4 ainda permite visualizar as alterações expressivas nos percentuais referentes à distribuição dos recursos entre os ministérios, ocorrida entre 2008 e 2009. Uma das modificações diz respeito à perda de expressividade do MDA no PTC (com o recuo de $26,5 \%$ para $17 \%$ ) e o consequente aumento do MS (subindo de 9,4\% para 15,7\%). Já de 2009 para 2010 não ocorreram mudanças substanciais, com exceção do MDS, que teve concentração ainda maior em relação aos demais ministérios (saindo de 37,9\% para $41,4 \%$ ), o que ampliou o controle do programa em apenas seis ministérios. 
Figura 4. Recursos previstos pelo PTC por ministério (2008 a 2010).

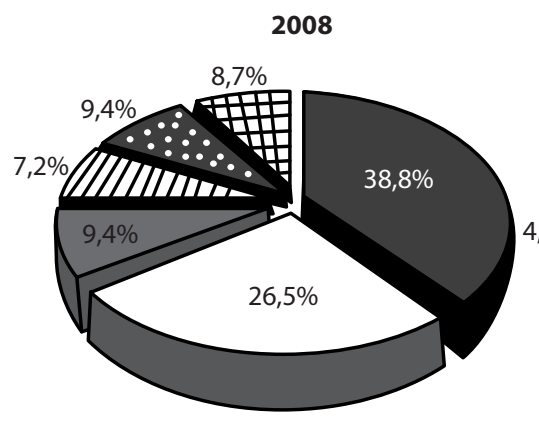

MDS

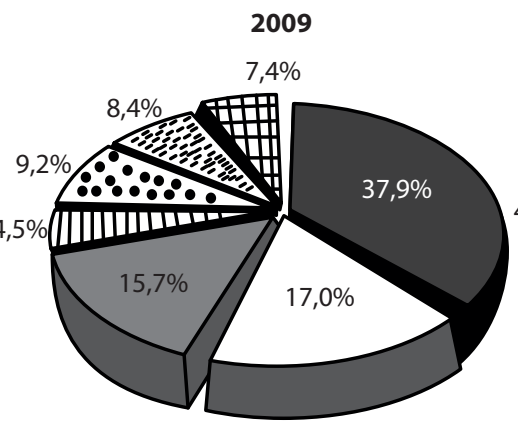

MDA $\square$ MS 国MME $\forall$ MF

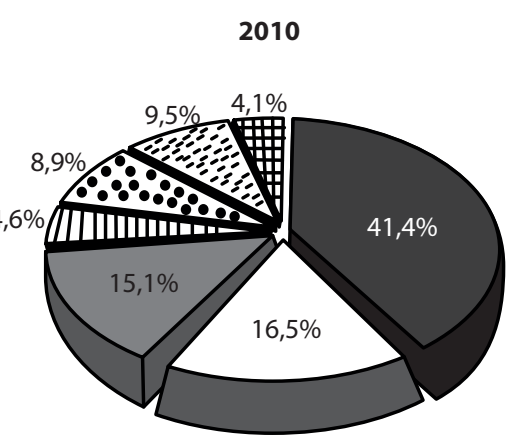

.:. MinC

Fonte: Brasil/Portal da Cidadania (2010).

Essa concentração em determinados ministérios é reflexo do grande peso que algumas ações possuem no PTC. Isso fica evidente quando na análise dos seis instrumentos que mobilizam recursos maiores (Bolsa Família, Benefício de Prestação Continuada à Pessoa Idosa, Benefício de Prestação Continuada ao Deficiente, Pronaf, Luz para Todos e Cresce Nordeste), pois eles representam $60 \%$ dos valores previstos ao programa, restando pouco mais de um terço às outras ações. Não é por acaso que três das seis principais ações são oriundas do MDS. Portanto, existe uma concentração em alguns eixos gerais do programa, que estão vinculados a determinados ministérios e, sobretudo, a algumas ações em especial.

Uma importante inovação implementada pelo PTC na gestão de programas governamentais foi a territorialização das ações, uma forma de garantir que o volume de recurso previsto inicialmente na Matriz de Ação Federal chegue a determinado espaço de modo impreterível. Essa estrutura, que identifica o local que será beneficiado pela política pública, não tem sido uma tática adotada pelo sistema corporativo nacional (Orçamento Geral da União, Lei de Diretrizes Orçamentárias etc.), que em vez de uma perspectiva gerencial territorial acaba trabalhando com valores macros que não designam o espaço de atuação dos instrumentos de intervenção.
Esta estratégia de territorialização das ações é objeto da atuação e difusão pelo Comitê Gestor Nacional, pois garante que os territórios empobrecidos e com baixo dinamismo econômico tenham acesso seguro sobre algumas linhas. Além disso, esse mecanismo tem evitado a concentração de recursos naqueles Territórios da Cidadania mais desenvolvidos e organizados, embora não consiga evitar uma aplicação maior de recursos em determinados municípios no interior desses territórios.

Entretanto, no momento em que o valor passa a ser territorializado, torna-se difícil que ele seja investido em outro local. Assim, se o recurso foi direcionado a um local no momento da construção do orçamento e o mesmo não tiver sido executado, ele acaba regressando para a fonte, geralmente sem ser implementado, pois uma vez definido o seu destino, a aplicação daquela rubrica em outro espaço fica comprometida. Isso tem feito com que algumas ações não sejam territorializadas, principalmente aquelas efetivadas por meio da demanda (projetos).

No momento em que os valores são carimbados, isto é, apresentam um destino de execução, e não há interesse naquele território para o qual foi direcionado o recurso ou há algum problema na sua contratação, esse valor dificilmente será encaminhado para outro lugar, mesmo havendo lá uma demanda por este instrumento. 
Nesse sentido, os ministérios territorializavam algumas ações tendo por base uma demanda potencial existente, mas como esta não se transformava em demanda real acabava-se perdendo aquele recurso. Essa situação tem desestimulado a territorialização de alguns programas. Entretanto, isso pode acabar favorecendo justamente os territórios mais estruturados em detrimento daqueles com maior dificuldade em efetivar suas demandas, mesmo estes últimos apresentando necessidade mais elevada de recursos.

Outra condicionalidade que reduziu a territorialização do orçamento foi a baixa capacidade de alguns órgãos conseguirem direcionar as suas ações para os territórios de forma prévia. Esse tem sido um problema presente no PTC devido à falta de clareza de determinados ministérios em definir os lugares que apresentam as maiores carências. Nesse caso, a possibilidade de concentrar os recursos nos territórios mais estruturados aumenta de forma abrupta, pois é ignorado qualquer mecanismo que direcione o orçamento para aqueles lugares com maior demanda potencial. É o caso, por exemplo, do Ministério da Pesca e Aquicultura (MPA) e do Ministério do Trabalho e Emprego (MTE), onde $100 \%$ do orçamento não foi territorializado em 2009 e em 2010. Próximos desta situação se encontram o Ministério da Integração Nacional (MIN) e o Ministério da Agricultura, Pecuária e Abastecimento (Mapa), em que ambos possuem apenas $13 \%$ dos seus recursos investidos no PTC direcionados previamente a determinados Territórios da Cidadania.

Os recursos territorializados em 2009 e 2010 aproximaram-se de $93 \%$ do total, mostrando grande esforço em "carimbar" os valores do PTC. Esse elevado percentual está atrelado aos principais ministérios do programa - em volume de recursos empregados - que territorializaram previamente $100 \%$ do seu orçamento para os Territórios da Cidadania. Isso tem ocorrido com o MDS, o MS, o Ministério das Cidades (Mcid), o Ministério de Minas e Energia (MME) e o Ministério da Fazenda (MF), tanto em 2009 quanto em 2010. Em alguns casos a territorialização por parte destes ministérios não apresentou dificuldade, pois suas ações se constituem em transferências diretas para os municípios.

Em alguns temas específicos houve mudança substancial de 2009 para 2010, como foi o caso das "Ações Fundiárias" e "Educação e Cultura". Nas "Ações Fundiárias" as metas não territorializadas subiram de $48,5 \%$ para $88,8 \%$. Uma das motivações para esse processo foi que a identificação dos territórios onde haveria a compra de terra para a reforma agrária acabou gerando, em alguns casos, a elevação do preço das áreas, encarecendo a sua aquisição pelo governo. Paralelamente, o fato de identificar os locais destas áreas acabava orientando a agenda de mobilizações dos movimentos sociais, que se organizavam a partir dos dados territorializados.

Já no tema "Educação e Cultura", os recursos territorializados caíram de 88\% em 2009 para $32,6 \%$ em 2010. Esta queda ocorreu pelo fato de que várias ações de 2009 foram direcionadas para alguns territórios que detinham uma demanda potencial, mas que acabou não sendo efetivada seja por desinteresse dos proponentes ou por dificuldade de contratação. Desta forma, a territorialização impediu o repasse dos recursos para outros locais que apresentavam projetos na área. Esta situação trouxe uma baixa execução orçamentária (somente $50 \%$ dos valores previstos foram pagos) por não poderem aplicar os recursos territorializados em outras localidades que apresentavam demanda. Para tanto, em 2010 as ações restritas a esse tema não foram territorializadas para que os ministérios responsáveis pelos instrumentos tenham flexibilidade maior no momento de empenhar os recursos.

Em suma, ao mesmo tempo em que a territorialização do orçamento se apresenta como importante inovação trazida pelo Programa Territórios da Cidadania, na medida em que "carimba" mais de $90 \%$ dos recursos previstos, essa característica se coloca como um desafio central na gestão de políticas públicas, pois passa a exigir dos gestores um conhecimento das demandas locais e dos principais entroncamentos (operativos e operacionais) que impede a sua efetivação. 
Figura 5. O papel do Colegiado nas ações do PTC (\% sobre o valor previsto).

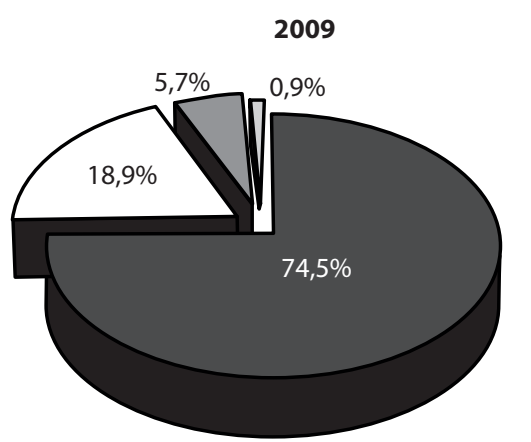

Controle social



Fonte: Brasil/Portal da Cidadania (2010).

De forma diferente do que acontece com o Pronat, onde o Colegiado Territorial possui função deliberativa sobre todas as ações, no PTC este conselho tem quatro diferentes atribuições: controle social, mobilização e articulação, ações consultivas e ações deliberativas ${ }^{6}$.

Embora seja diversificado o papel do Colegiado no PTC, existe uma distribuição desigual. Isso porque as funções de controle social e mobilização e articulação representam a maioria das ações (mais de dois terços) e do volume de recursos

6 Controle Social: ação do ministério proponente de forma definida, sendo que o órgão apenas informa ao Colegiado a sua implementação no Território. Exemplos: Bolsa Família, Luz para Todos, Crédito do Pronaf, Fundo Nacional de Habitação de Interesse Social e Aquisição de terras. Mobilização e articulação: ação cuja definição da execução não depende só do Ministério/Órgão Gestor, mas também de outros atores (municípios, estados, conselhos setoriais etc.). Neste caso, os Colegiados devem se articular com os demais atores responsáveis pela deliberação final, procurando contribuir com a implementação da ação no Território. Exemplos: Programa de Aquisição de Alimentos (MDS), Programa de Cisternas, Arranjos Produtivos Locais e Construção de Escolas. Consultivo: o gestor disponibiliza as ações e pede ao Colegiado sugestões de aplicação dentro do Território da Cidadania, sendo que essa proposição pode ser acatada ou não (muitas vezes a inadimplência das prefeituras e dos estados impede que a indicação do conselho seja incorporada na orientação da ação). Exemplos: Assistência Técnica e Extensão Rural, Biodiesel, Fomento a Atividades Pesqueiras e Aquícolas, Programa Nacional de Crédito Fundiário e Programa de Aquisição de Alimentos (MDA). Deliberativo: não é o ministério que define onde as ações serão aplicadas no território, mas sim o Colegiado. Exemplos: Pronat, Programa Arca das Letras, Implantação das Casas Digitais Rurais e Elaboração de Estudos de Potencialidade Econômica - ambos restritos ao MDA. previstos (93\%). Deste modo, os instrumentos que demandam um papel mais ativo e decisivo dos Colegiados Territoriais (consultivos e deliberativos) acabam tendo uma pequena parcela das ações e dos recursos (que no caso das ações deliberativas não chega a $1 \%$ do montante do PTC).

É importante perceber que mesmo sendo reduzida a função do Colegiado, entre 2009 e 2010 ela acabou diminuindo ainda mais, pois as ações de controle social (nas quais o conselho territorial apresenta um reduzido poder de decisão, para não dizer zero) ampliaram-se de 74,5\% para 80\% (a Figura 5 permite visualizar essa alteração a partir do valor previsto). Paralelamente, os instrumentos consultivos e deliberativos acabaram reduzindo-se ainda mais, tanto no número de ações quanto no montante de recursos ${ }^{7}$.

A distribuição dos recursos previstos pelo PTC entre as regiões brasileiras de 2008 a 2010 apresentou algumas alterações, incluindo nos dois últimos anos o aumento do peso relativo do Nordeste (que passou de $48,2 \%$ para $56,2 \%$ ) e a redução do Norte (de 22,3\% para 16,6\%). Apesar da nova configuração no número de Territórios da Cidadania de 2008 para 2009 (de 60 para 120), as demais regiões mantiveram o percentual

\footnotetext{
7 Uma das explicações referentes à redução do número de ações deliberativas se dá pelo fato de que muitas delas se reportavam à elaboração de estudos e à criação de planos, operados somente no primeiro ano de constituição do Território da Cidadania. Como não foram implementados novos territórios, essas ações foram excluídas da Matriz federal.
} 
Figura 6. Participação dos recursos previstos pelo PTC por região brasileira (2008 a 2010).

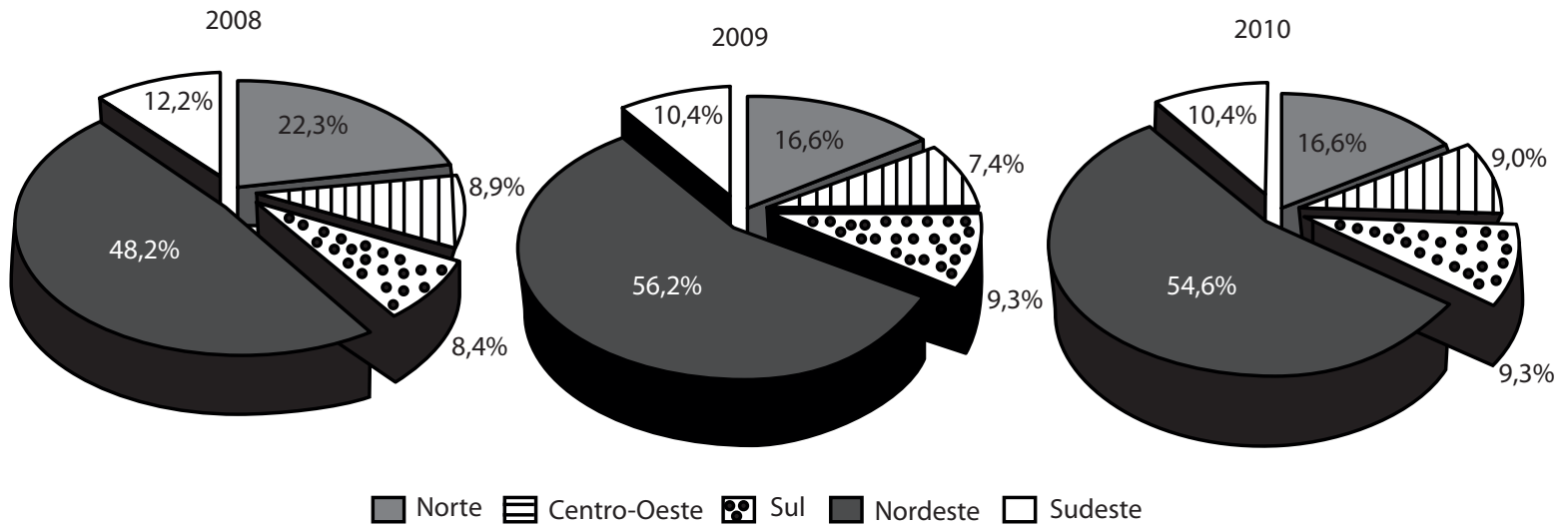

Fonte: Brasil/Portal da Cidadania (2010).

sobre os recursos previstos de forma semelhante: o Sudeste reduziu de $12 \%$ para $10 \%$, o Sul permaneceu próximo dos $9 \%$ e o Centro-Oeste teve oscilação de 7\% a 9\% (cf. Figura 6).

Outro dado importante é que apesar de o Nordeste concentrar $46,7 \%$ dos Territórios da Cidadania e $50,7 \%$ dos municípios localizados dentro do PTC, esta região detém 54,6\% dos recursos previstos em 2010 (cf. Figura 6), apontando que existe um direcionamento ligeiramente maior dos valores aplicados no programa para esta região. Essa situação pode ser resultado do processo de gestão territorial, por meio da territorialização dos recursos, onde os gestores federais passam a direcionar os valores a partir das especificidades locais e das possíveis demandas existentes. Embora este processo seja positivo ao Nordeste, ele tem se apresentado desproporcional em relação ao Norte, que detém 22,5\% dos Territórios da Cidadania e somente $16,6 \%$ dos recursos previstos.

\subsection{Execução financeiro-orçamentária do PTC}

Diferentemente do Pronat, que dispõe de dados sobre o valor previsto, disponibilizado, empenhado, contratado e pago, as informações no Programa Territórios da Cidadania restringem-se ao valor previsto $(2008,2009$ e 2010) e pago (2008 e 2009). Apesar disso, é possível calcular, embora com menor detalhamento, a execução financeiro-orçamentária do PTC por meio do valor pago sobre a dotação prevista no início de cada período.

Em 2008, a execução orçamentária do PTC alcançou $72 \%$ apesar de o programa ser lançado somente em fevereiro, o que implicou que a matriz de ações nos territórios ficasse definida em abril. Além disso, como a maioria das ações foi efetuada por meio de convênios, o fato de ser um ano eleitoral dificultou o empenho dos recursos, visto que as contratações foram suspensas a partir de julho e retomadas somente em outubro. Nesse sentido, o pagamento de $72 \%$ dos valores previstos representa um saldo expressivo, sendo superior ao Pronat na maioria dos anos. Como algumas ações foram contratadas como "restos a pagar", devido, inclusive, aos problemas apresentados acima, em 2009 esse acompanhamento ainda estava sendo feito. Para tanto, se considerarmos o que foi pago em 2008 e 2009 referentes aos valores previstos em 2008, a execução chegou a 77,8\% (cf. Tabela 4$)^{8}$.

8 Os dados da execução financeiro-orçamentária de 2008 apresentados neste artigo referem-se até 31 de dezembro de 2009. Nesse caso, estão incluídos os valores pagos em 2008 e as rubricas que ficaram incluídas em "restos a pagar" e que foram quitadas em 2009. 
Tabela 4. Valor previsto e valor pago no PTC por grupo de ações (2008) - valores correntes em R\$.

\begin{tabular}{lcccc}
\hline \multicolumn{1}{c}{ Tema } & Ações & Valor Previsto (R\$) & Valor Pago (R\$) & Pago/Previsto \\
\hline Ações Fundiárias & 8 & $322.319 .943,45$ & $178.661 .691,84$ & $55,4 \%$ \\
Apoio à Gestão Territorial & 12 & $19.918 .679,77$ & $18.192 .005,54$ & $91,3 \%$ \\
Direitos e Desenvolvimento Social & 12 & $4.830 .370 .807,62$ & $4.974 .753 .114,88$ & $103,0 \%$ \\
Educação e Cultura & 18 & $563.423 .573,34$ & $498.152 .416,36$ & $88,4 \%$ \\
Infraestrutura & 27 & $3.150 .886 .020,39$ & $1.092 .254 .507,06$ & $34,7 \%$ \\
Organização Sustentável da Produção & 85 & $2.452 .374 .482,58$ & $1.654 .152 .673,67$ & $67,5 \%$ \\
Saúde, Saneamento e Acesso à Água & 18 & $1.438 .889 .061,33$ & $1.525 .132 .503,97$ & $106,0 \%$ \\
Total & $\mathbf{1 8 0}$ & $\mathbf{1 2 . 7 7 8 . 1 8 2 . 5 6 8 , 4 8}$ & $\mathbf{9 . 9 4 1 . 2 9 8 . 9 1 3 , 3 2}$ & $\mathbf{7 7 , 8 \%}$ \\
\hline
\end{tabular}

Fonte: Brasil/Portal da Cidadania (2010).

A partir da Tabela 4 é possível visualizar o pagamento dos recursos de 2008 sobre o orçamento previsto por Temas do Programa. As linhas voltadas à "Direito e Desenvolvimento Social" e "Saúde, Saneamento e Acesso à Água" apresentaram execução superior àquela planejada $(103 \%$ e $106 \%$, respectivamente). Esse resultado se deve, além da inclusão de novos beneficiários, à forma de se efetivar o pagamento, pois se trata geralmente de uma despesa corrente com fluxo contínuo, isto é, mensalmente os recursos são pagos sem contar necessariamente com a apresentação de novos projetos (ex. Bolsa Família). Nesse sentido, são ações que não tiveram alterações significativas com a entrada no PTC, pois mantiveram sua estrutura de intervenção. Isso favoreceu a sua execução orçamentária, visto que o desembolso foi feito de forma ininterrupta de janeiro a dezembro - mesmo em um ano eleitoral e com o início efetivo do programa em abril.

Por outro lado, as ações de infraestrutura em 2008 apresentaram um reduzido pagamento (abaixo de 35\%), apesar de incluir as rubricas quitadas até dezembro de 2009. Essa situação é próxima daquela discutida anteriormente com o Proinf (vinculado ao Pronat), pois depende fundamentalmente da contratação com entes federados (prefeituras municipais e estados) e da sua negociação com agências bancárias, o que gera um trâmite administrativo mais lento, atrasando o pagamento. Os instrumentos vinculados às "Ações Fundiárias" e "Organização Sustentável da Produção" também tiveram execução orçamentária abaixo da média, alcançado $55,4 \%$ e $67,5 \%$, respectivamente.
Em 2009, o PTC apresentou execução orçamentária maior que em 2008, alcançando $77,8 \%$ (valores referentes à dezembro de 2009). É importante destacar que $85 \%$ dos recursos previstos foram empenhados, o que significa que acabaram incluídos nos "restos a pagar" e que, por isso, podem ser quitados até os próximos cinco anos. Assim como em 2008, as ações de "Direito e Desenvolvimento Social" se destacam pela elevada execução (105\%) e as de "Infraestrutura" apontam para um reduzido valor pago $(38,9 \%)$, embora esse percentual tenha se elevado em relação a 2008 dada a experiência do programa e ao fato de não se tratar de ano eleitoral (cf. Tabela 5).

Apesar de o tema "Infraestrutura" ter execução orçamentária abaixo de $50 \%$, o que chamou atenção em 2009 foram os instrumentos relacionadas ao "Apoio à Gestão Territorial", no qual o valor pago sobre o previsto não chegou a 5\% (cf. Tabela 5). Esse resultado ínfimo ocorreu porque as ações que representam $86 \%$ do volume de recursos deste eixo ("Elaboração do Plano Territorial de Desenvolvimento Rural Sustentável - PTDRS", "Formação de Agentes de Desenvolvimento" e "Apoio ao Fortalecimento da Gestão Social nos Territórios") não foram implementadas. Isso aconteceu devido à indefinição da renovação do convênio entre a Caixa Econômica Federal e o MDA, o que impossibilitava que fossem efetuados os contratos de repasse de recursos junto às entidades parceiras. Como esse problema foi resolvido apenas em novembro, ficou inviável o repasse dos recursos de 2009 em tempo hábil. 
Tabela 5. Valor previsto e pago no PTC por grupo de ações (2009) - valores correntes em R\$.

\begin{tabular}{lcccc}
\hline \multicolumn{1}{c}{ Tema } & Ações & Valor Previsto (R\$) & Valor Pago (R\$) & Pago/Previsto \\
\hline Ações Fundiárias & 13 & $516.803 .123,47$ & $277.593 .202,26$ & $53,7 \%$ \\
Apoio à Gestão Territorial & 13 & $23.348 .610,09$ & $886.371,09$ & $3,8 \%$ \\
Direitos e Desenvolvimento Social & 15 & $9.098 .521 .324,58$ & $9.568 .632 .675,28$ & $105,2 \%$ \\
Educação e Cultura & 46 & $1.342 .877 .879,36$ & $673.019 .718,55$ & $50,1 \%$ \\
Infraestrutura & 13 & $3.702 .870 .999,99$ & $1.440 .884 .389,29$ & $38,9 \%$ \\
Organização Sustentável da Produção & 74 & $5.943 .557 .001,43$ & $5.071 .334 .664,53$ & $85,3 \%$ \\
Saúde, Saneamento e Acesso à Água & 29 & $4.297 .359 .313,41$ & $2.347 .637 .140,66$ & $54,6 \%$ \\
Total & $\mathbf{2 0 3}$ & $\mathbf{2 4 . 9 2 5 . 3 3 8 . 2 5 2 , 3 3}$ & $\mathbf{1 9 . 3 7 9 . 9 8 8 . 1 6 1 , 6 6}$ & $\mathbf{7 7 , 8 \%}$ \\
\hline
\end{tabular}

Fonte: Brasil/Portal da Cidadania (2010).

Figura 7. Execução financeiro-orçamentária (valor pago/valor previsto) nos programas nacionais e nas suas ações no PTC (2009) - em \%.



* BPC - Benefício de Prestação Continuada.

Fonte: Siga Brasil/Senado Federal - LOA 2009 (2010); Brasil/Portal da Cidadania (2010).

Uma forma interessante para apontar a eficácia do PTC no que tange a execução financeiro-orçamentária das suas ações é por meio da comparação com os resultados das mesmas políticas ao nível nacional. Isso significa confrontar o volume de recursos pagos em relação ao valor previsto utilizando-se os dados gerais dos programas e as informações específicas da sua ação no PTC.

Se destacarmos as ações que representam $52,3 \%$ do total de recursos previstos em 2009 no PTC (Bolsa Família, Luz para todos, Pronaf e Benefício de Prestação Continuada à Pessoa Idosa e ao Deficiente), é possível perceber que a execução financeira dentro da política integrada é bem superior aos valores executados pelos programas isoladamente - apesar de serem ações onde o colegiado não tem função deliberativa.
Isso pode ser visto na Figura 7, onde os programas em nível nacional apresentaram execução abaixo daquela encontrada no PTC.

A partir dos resultados nacionais das políticas públicas analisadas na Figura 7, é possível visualizar que somente o Programa Bolsa Família teve ótima execução. Isso se deve ao fato de ser uma despesa corrente com fluxo contínuo e com desembolsos mensais. No caso dos outros instrumentos de intervenção os valores ficaram abaixo dos $60 \%$, pois o trâmite administrativo (que comumente envolve a abertura de edital, licitação, empenho, contrato e pagamento) dificulta a execução em apenas um ano. Concomitantemente, as ações do PTC apresentaram valores acima de $70 \%$, alcançando em três dos cinco instrumentos um pagamento superior ao que foi previsto. 
Portanto, é possível afirmar, a partir dos programas apresentados na Figura 7, que existe, de fato, uma execução financeiro-orçamentária mais alta e eficaz dentro do PTC em comparação com a implementação isolada da política mesmo sabendo que os Territórios da Cidadania são espaços mais fragilizados e empobrecidos, o que geralmente reduz as possibilidades de uma ampla efetivação dos recursos. Deste modo, a aproximação dos programas setoriais com a matriz territorial tem potencializado um maior desembolso se comparado com aqueles instrumentos que permaneceram avulsos. Apesar de o PTC se encontrar em uma situação embrionária (dado o pouco tempo de funcionamento), é possível afirmar que existe um processo inicial de sensibilização da política setorial com a questão territorial, ocorrendo nesse trajeto uma preocupação em cobrir as principais prioridades do meio rural.

A presença de resultados mais expressivos na execução orçamentária dos instrumentos integrados ao PTC está relacionada a uma série de fatores e condicionalidades. Uma das engrenagens desse processo se refere à gestão do programa, na qual cada Comitê procura atuar no acompanhamento das ações e na obtenção de resultados expressivos.

O fato de haver nos territórios um conhecimento das ações que são implementadas nesses espaços acaba estimulando que alguns Colegiados Territoriais e Conselhos Setoriais assumam de fato a função de "controle social". Isso se reflete positivamente na gestão do programa, pois oferece aos policy-makers federais um feedback das ações e, em alguns casos, pode gerar uma reorientação da política a partir da sua adequação às especificidades destes espaços. Concomitantemente, alguns prefeitos passaram a usar o fato de estarem em Territórios da Cidadania para exigir a aplicação dos recursos programados junto aos órgãos responsáveis pelas ações.

Nesta mesma direção, a territorialização das ações, que obriga a aplicação dos recursos nos espaços previamente definidos, tem alertado os atores locais sobre a disponibilidade de valores específicos para determinado território. Isso faz com que o colegiado pressione a sua execução, já que fica evidente a disponibilidade dos recursos para aquele local/região.

Em paralelo às iniciativas presentes nas escalas locais, alguns ministérios, por meio dos seus gestores, passaram a privilegiar a execução dos seus recursos nos Territórios da Cidadania dada as características e especificidades dessas localidades (elevados níveis de pobreza, baixo dinamismo econômico etc.). Isso auxiliou a readaptação ou a criação de novos instrumentos político-administrativos que visavam superar os principais gargalos presentes nas ações aderidas ao PTC, visto que as regióes integrantes deste programa são justamente aquelas que apresentam graves problemas de execução financeiro-orçamentária. A partir desse contexto foi possível visualizar algumas iniciativas de determinadas secretarias, que passaram a orientar as suas políticas pelas particularidades dos Territórios da Cidadania.

Um exemplo que pode ser citado se refere à linha de infraestrutura do Pronat (Proinf), na qual a SDT/MDA acrescentou um diferencial de valores para os projetos localizados no Norte do País, demonstrando o reconhecimento das particularidades daquela região. Outro caso ocorreu junto ao Ministério da Saúde, na ação que prevê a constituição de farmácias populares, onde os critérios de participação dos municípios foram flexibilizados a partir da sua integração ao PTC. Apesar de haver algumas experiências, como estas que acabamos de citar, onde a base territorial tem servido enquanto um espaço de reorientação da política, é preciso reconhecer que essas estratégias ainda são incipientes. Todavia, no momento em que as especificidades locais passam a ser consideradas e reconhecidas na implementação das políticas, isso tem auxiliado positivamente na execução financeiro-orçamentária.

Outra estratégia observada ao nível dos ministérios, por pressão da Casa Civil e do Ministério do Planejamento, é uma preocupação em manter os recursos direcionados ao PTC, contingenciando políticas que não estão 
programadas para os Territórios da Cidadania. Isso permite maior execução nas áreas territoriais, na medida em que a presença de cortes orçamentários fica reduzida nesses espaços, enquanto que aqueles municípios que não estão integrados ao programa acabam ficando mais vulneráveis a esse tipo de restrição.

Apesar de alguns exercícios nacionais de otimização da execução das ações do PTC, as desigualdades regionais e estaduais permanecem nos percentuais de pagamento dos recursos previstos. No Sul do Brasil a média esteve acima de 90\% tanto em 2008 quanto em 2009, sendo que em Santa Catarina esse dado foi maior que $100 \%$ nos dois anos. No lado oposto estão as regiões Norte e Centro-Oeste, onde mais de um terço e um quarto dos valores previstos, respectivamente, não foram pagos em 2008 e 2009 - Roraima e Mato Grosso foram os estados que tiveram execução orçamentária inferior a $40 \%$ em 2008. Entretanto, em 2009, nenhum estado apresentou valor inferior a $58 \%$, apontando para avanço significativo.

Os dados encontrados nas regiões Norte e Centro-Oeste refletem a própria situação estrutural dos territórios presentes nesses espaços, já que muitas vezes estas áreas encontram-se isoladas, com reduzido quadro técnico especializado e com vários problemas administrativos. Outra situação que tem provocado baixa execução, em especial na região Norte, diz respeito à incompatibilidade do período orçamentário com as condicionalidades edafoclimáticas daquela área. Com efeito, o processo inicial do programa (construção da matriz de ações, definição dos recursos para o território, abertura de edital, seleção de projetos etc.) avança até meados de outubro, restando às demais etapas (empenho, contrato e pagamento) somente os meses de novembro e dezembro, que compreendem justamente o período das chuvas na Amazônia (entre novembro e março). Essa característica impossibilita que as ações sejam implementadas no mesmo ano que foram previstas (especialmente as obras de infraestrutura), pois a temporada da cheia dos rios dificulta o tráfego entre determinadas áreas e isola muitas comunidades. Deste modo, os projetos acabam sendo contratados no mesmo ano, o que assegura os recursos previstos, mas são pagos somente no ano seguinte, pois no período das chuvas o custo de implementação é maior e a qualidade dos serviços dificilmente é adequada.

Em relação à execução orçamentária no PTC segundo os ministérios, é possível afirmar que alguns órgãos apresentam participação ativa, mantendo elevadas taxas de pagamento e/ ou buscando melhorá-las (MDS, MAPA, MDA e MME). Por outro lado, existem ministérios que, apesar de integrarem o programa, não obtiveram saldos satisfatórios, como é o caso do Ministério das Cidades, Ministério da Justiça, Ministério do Meio Ambiente e a Secretaria de Políticas de Promoção da Igualdade Racial (SEPPIR), que em 2009 apresentaram execução de $12 \%$ dos recursos. Deste modo, fica evidente uma grande disparidade entre a atuação dos diferentes ministérios, apontando graus distintos de comprometimento com a gestão territorial de políticas públicas para o meio rural.

Esta análise do PTC clareia os avanços da política territorial em relação ao Pronat, pois inovou ao mobilizar diferentes ministérios e fontes de recursos, além de territorializar mais de 90\% das suas ações e de envolver os diferentes espaços de gestão do programa na busca por resultados expressivos na execução financeiro-orçamentária. Por outro lado, alguns elementos já presentes no Pronat não ganharam o mesmo peso no PTC, apesar da sua importância no desenvolvimento das políticas desta natureza. Isso ocorreu com a gestão territorial, que tem um montante de recursos ínfimos, e com o papel dos colegiados, que foi fortemente minimizado.

Outro desafio do PTC é reduzir a concentração de recursos em determinados ministérios e ações, procurando tornar a participação dos diferentes órgãos mais equitativa e equilibrada. Na mesma direção, torna-se necessária a articulação, ao nível do Comitê Gestor Nacional, dos técnicos e funcionários responsáveis pelos orçamentos de cada um dos 22 ministérios envolvidos, no sentido 
de homogeneizar linguagens, temporalidades e definir prioridades na aplicação dos recursos financeiros. Isso tem evoluído positivamente no período recente, mas ainda há um grande esforço de articulação técnico-financeira a ser alcançado.

\section{Considerações finais}

Os resultados apresentados nesse estudo mostraram a complexidade e, ao mesmo tempo, as inovações que o arranjo institucional na operação de políticas em escala territorial traz para a cena orçamentária, seja no que tange ao levantamento e lastreamento de fontes dos recursos alocados, seja no que se refere à forma de aplicação desses recursos segundo áreas geográficas e linhas programáticas de ação.

Também, pode-se constatar que as experiências aqui analisadas (Pronat e PTC) relataram alcances e limites no quesito da prática de financiamento das ações territorializadas que movimentaram e movimentam as ações dos diferentes atores sociais envolvidos, incluindo os diversos órgãos públicos inscritos nos programas suprarreferidos.

Ao longo do trabalho foram destacados os resultados encontrados no processo de execução das políticas. Em particular deve-se apontar o caráter inovador dos programas ao direcionar os recursos atinentes ao desenvolvimento das áreas objeto de ação, dos municípios para uma escala logo acima, mesmo que esta última não tenha, ainda, um consolidado amparo legal. Isso tem impedido, por sua vez, que os recursos destinados aos projetos de investimento (inscritos nas linhas programáticas com menor capacidade de execução orçamentária) apresentem desempenho mais satisfatório, pois dependiam impreterivelmente do envolvimento das prefeituras ou dos órgãos dos governos estaduais, o que nem sempre é possível (seja por motivos políticos, seja em função da inadimplência dessas unidades) ${ }^{9}$.

9 A aplicação do Projeto de Lei assinado pelo Presidente da República no dia 24 de março de 2010, que dispõe sobre a não exigência das prefeituras de documentos que comprovem a adimplência com a União no momento de contratar os projetos, facilitará o acesso aos recursos federais do Pronat e
Observadas as performances de ambos os programas, é evidente que o PTC apresenta desafios maiores, do ponto de vista orçamentário, em função de uma institucionalidade mais complexa. Assim, uma melhor capacidade de planejamento do programa parece ser necessária, visto ser o mesmo um agregado de ações aderidas anualmente pelos ministérios, impossibilitando às vezes a elaboração de uma estratégia de médio prazo e fragilizando a sua ossatura orçamentária.

Viu-se ainda que, apesar do progressivo aumento na capacidade de gasto, a vinculação da apresentação dos projetos territoriais ao ano fiscal implica que boa parte dos recursos necessita ser empenhada e propostas contratadas somente nos meses de novembro e dezembro, transferindo invariavelmente o efetivo pagamento para os anos seguintes, comprometendo o desempenho dos projetos territoriais estratégicos.

O espaço representado pelo Colegiado, como uma instância de participação, discussão e decisão, é ponto alto na ossatura institucional dos programas. No entanto, na questão financeiro-orçamentária, a participação dos atores territoriais responsáveis pela implementação dos projetos nas reunióes desse fórum deve ser estimulada, pois em alguns casos os recursos deixam de ser aplicados e acabam retornando ao Tesouro porque as entidades proponentes não procedem de forma correta a execução das ações. Do mesmo modo, a possibilidade de contar com representantes da CEF nessas arenas poderia facilitar o fluxo de recursos destinados aos territórios, permitindo uma avaliação mais precisa de cada caso. De qualquer forma, espera-se que com o maior envolvimento dos atores territoriais, aumente também o número de ações deliberativas a cargo do Colegiado e que as mesmas - no caso do PTC - não se restrinjam aos instrumentos sob a responsabilidade do MDA.

Ao longo do artigo constatou-se que as emendas parlamentares passaram a deter um peso considerado no funding dos programas.

PTC e, provavelmente, a implementação das ações dos projetos territoriais. 
Se por um lado isso aponta para o carreamento de recursos a partir de uma "nova" fonte, aumentando o volume de dinheiro aplicado nos programas, por outro, tal engrenagem pode impor aos territórios projetos que sejam do interesse de determinado parlamentar e/ou do seu grupo de apoio local, sem que os mesmos sejam discutidos nas instâncias previstas pelos programas. Assim, seria desejável articular, na medida do possível, os recursos oriundos das emendas parlamentares com os projetos definidos democrática e coletivamente nos fóruns territoriais, evitando que sejam financiados justamente os projetos não aprovados e/ou discutidos nas esferas representativas.

Em suma, embora os recursos destinados aos programas ainda possam ser objeto de um aumento substancial, melhorando a qualidade das intervenções, e sua aplicação possa igualmente ser mais ágil e interativa (atores/ colegiados/ministérios), é evidente que o exercício que os diferentes participantes desse processo se propuseram a operar - isto é, a busca de projetos estratégicos que superem a escala estritamente local - explicitou, por um lado, a complexidade - para não dizer as agruras - do ferramental orçamentário e, por outro, abriu a possibilidade de melhorar substantivamente o accountability da política, além de apontar para uma maior efetividade das ações quando assentadas numa base mais abrangente do ponto de vista espacial e setorial. Isso ficou claro quando comparado o mesmo tipo de ação e sua aplicação no plano estritamente setorial ao nível nacional e no plano definido territorialmente no âmbito do PTC.

Finalmente, é possível pensar, adicionalmente, que os recursos a fundo perdido que financiam os projetos territoriais objeto da política, mesmo com valores relativamente reduzidos, podem se tornar um fator potencializador na dinâmica territorial, estimulando a busca por programas de financiamento complementares.

\section{Referências bibliográficas}

ABRAMOVAY, R.; VEIGA, J. E. Novas instituições para o desenvolvimento rural: o caso do Pronaf. Brasília: IPEA, p. 49, 1999. (Textos para discussão).

BONNAL, P. Territórios da Cidadania: evolução ou revolução das políticas públicas no meio rural brasileiro? Boletins do OPPA, 2008. Disponível em: < http://www. ufrrj.br/cpda/oppa/ > Acesso em: set. de 2009.

BRASIL. Controladoria-Geral da União (CGU). Balanço Geral da União de 2006. Disponível em: < http://www. cgu.gov.br/Publicacoes/ PrestacaoContasPresidente/>. Acesso em: set. de 2009.

BRASIL. Controladoria-Geral da União (CGU). Balanço Geral da União de 2007. Disponível em: < http://www. cgu.gov.br/Publicacoes/PrestacaoContasPresidente/>. Acesso em: set. de 2009.

BRASIL (2010). Ministério da Fazenda / Tesouro Nacional. Execução Orçamentária por Programa (2009). Brasília.

BRASIL (2009). Ministério do Desenvolvimento Agrário / Secretaria de Desenvolvimento Territorial. Execução Financeiro-Orçamentária (2003 a 2008). Brasília: SDT.

BRASIL (2004). Ministério do Desenvolvimento Agrário / Secretaria de Desenvolvimento Territorial. Infra-Estrutura. Brasília: SDT.

BRASIL (2010a). Portal da Cidadania. Relatórios $e$ informações do Programa. Disponível em: < http://www. territoriosdacidadania.gov.br/>. Acesso em: mar. de 2010.

BRASIL (2009a). Presidência da República. Mensagem ao Congresso Nacional2009. Brasília: Presidência da República, Secretaria-Geral da Presidência da República.

BRASIL (2008). Presidência da República. Decreto de 25 de fevereiro de 2008. Brasília: Presidência da República, Casa Civil.

CAZELLA, A.; BURIGO, F. Cenário atual e proposições para se fortalecer sistemas de financiamento territorial no Brasil. Florianópolis: OPPA/UFSC/IICA. Relatório de Pesquisa. 2009.

DELGADO, N.; ZIMMERMANN, S. Gestão de políticas públicas de desenvolvimento rural no contexto das novas institucionalidades - Relatório 2. Rio de Janeiro: OPPA/ CPDA/ UFRRJ/IICA. 2008. 
GASQUES, J. G., BASTOS, E. T. Gastos públicos na agricultura brasileira. Política Agrícola, v. XVIII, n. 2, abr.jun., p. 18-29, 2009.

HESPANHOL, R. A. de M. Pronaf Infra-Estrutura e Serviços Municipais e Associações de Produtores Rurais em Municípios selecionados da região de Presidente Prudente, Estado de São Paulo. Informações Econômicas, SP, v. 36, n. 5, p. 15-24, 2006.

LEITE, S.; DELGADO, N.; BONNAL, P.; KATO, K. Desenvolvimento territorial: articulação de políticas e atores sociais. OPPA/CPDA/UFRRJ-IICA/Fórum DRS. Rio de Janeiro: CPDA/UFRRJ. (Relatório de Pesquisa) 2007.

SIGA BRASIL - SENADO FEDERAL (2010). Ехесução orçamentária anual por programa. Disponível em: <ww9. senado.gov.br/portal/page/portal/orcamento_senado/ LOA/> . Acesso em: set. de 2010.
TORRENS, J. C. S. Território e desenvolvimento: a experiência de articulação territorial do Sudoeste do Paraná. Deser: Curitiba, 2007. (Projeto de Cooperação Técnica MDA/FAO).

VIGNA, E. Baixa execução do Orçamento Agrário prejudica famílias assentadas. Notícias do INESC, 2012.

VIGNA, E. Reforma Agrária é atingida pelo corte orçamentário. Artigos INESC, 2011.

VIGNA, E. Alimentação, PLOA 2011e Dívida Pública. Nota Técnica (INESC), 171, 2010.

VIGNA, E. Governo infla a execução orçamentária dos programas da função agrária em 2008. Nota Técnica (INESC), 147, 2009.

VIGNA, E. Análise Resumida da Execução Orçamentária do Ministério do Desenvolvimento Agrário - MDA. Artigos INESC, 2004. 